\title{
高齢発症慢性関節リウマチの臨床的特徵
}

\author{
九州中央病院整形外科 \\ 時 任毅・増 田 祥 男 \\ 小橋 芳 浩・花 田 能 成 \\ 九州中央病院リハビリテーション科 \\ 中川悟
}

\section{Clinical Features of Elderly-onset Rheumatoid Arthritis}

by

\author{
Takeshi Tokito, Sachio Masuda, Yoshihiro Kohashi \\ and Yoshinari Hanada \\ Department of Orthopaedic Surgery, \\ Kyushu Central Hospital \\ Satoru Nakagawa \\ Department of Rehabilitation, \\ Kyushu Central Hospital
}

To elucidate the clinical characteristics of patients with elderyly-onset rheumatoid arthritis (EORA), we compared the clinical features, laboratory data, and clinical course of 17 patients with elderly-onset (age at onset; over 60 years, average 63.0 years with) 19 patients with younger-onset (below 50 years, average 38.3 years). The group with EORA had an increased incidence of hypertension, diabetes mellitus, cardiovascular disease, ischemic heart disease. There was no significant difference in the levels of ESR, CRP, IgG-RF titer, serum IgG concentration at entry, and the clinical course during two years follow-up between the 2 groups. In spite of EORA patients having a higher prevalence of complications to drugs including disease-modifying anti rheumatic drugs (DMARDs) and steroids, we considered that DMARDs (especially GST) and steroids must be used to prevent rapid bone destruction. In addition, surgical procedures including joint replacement were recommended to maintain the EORA patients activity of daily living.

Key words : Rheumatoid Arthritis（慢性関節リウマチ), elderly-onset (高齢発症), clinical features（臨床的特徴）

\section{はじめに}

慢性関節りウマチ（RA）は女性に多く好発年令は 30 歳から 40 歳代であるが, 最近では高齢発症の RA も多く認められるようになってきた.これらの臨床像 については諸家からの多くの報告があるが, まだ一致 した見解は得られていない. 今回当科において加療し た高齢（60歳以上）発症 RA 患者に対して検討を加
え，若干の知見を得たので報告する．またQOL の改 善のため手術的治療（人工関節置換）を行った例に対 しても考察を述べる.

\section{対象と方法}

60 歳以降に発症し当科において 2 年以上加療した $\mathrm{RA}$ 患者（1987 年 ACR 診断基準を满たす）17 名を 対象とした。その内訳は男性 2 名, 女性 15 名であり 
調査時年令は $61 \sim 78$ 歳 (平均 69.4 歳), 発症時年令 は 60〜 77 歳 (平均 63.0 歳), 罹病期間は 6 ケ月〜 12 年（平均 3.4 年）であった。なおその対照として 50 歳未満に発症した RA 患者 19 名（男性 4 名，女性 15 名）についても比較検討した。対照群の調査時年 令は $22 \sim 65$ 歳 (平均 42.4 歳), 発症時年令 $20 \sim 45$ 歳 (平均 38.3 歳), 罹病期間は 6 ケ月〜 22 年 (平均 7.1 年) であった.この 2 群に対し血沈, CRP, RAHA, IgG$\mathrm{RF}$ ，血清 IgG，ランズバリー活動性指数（LI）につ いて 2 年間の推移を調べた他，抗リウマチ薬の副作用 を含む継続率および合併症についても検討を加えた.

結果

臨床検査値の推移は表 1 の如くであり，初診時高齢 発症 RA 患者において炎症所見は高値を示したが,
対照群とは有意な差は認めなかった。しかし RAHA は有意に高值を示し，悪性慢性関節リウマチの診断基 準のひとつである 2560 倍以上の值を示すものも 17 例 中 3 例（対照群では 19 例中 2 例）に認めた。なお RAHA 陰性例を 3 例（対照群では 5 例）に認めた。 IgG-RF は高齢発症群において平均 2.5 と高值を示し, 2.0 以上を陽性とした場合 17 例中 6 例が陽性であっ た．しかし対照群においても平均 1.9 と有意差を認め ず 19 例中 4 例に陽性例を認めた。血清 IgG は平均值 において有意差を認めなかったが，高齢発症群におい て 2000 以上の高值例を 8 例（対照群では 2 例）に認 めた．LIにおいては有意差を認めなかった。

1 年後の調查時では両群ともに炎症所見は軽快傾 向を示し, RAHAにおいても改善傾向を認めたが, IgG-RF は高齢発症群にて平均 1.7 と低下を認めるも

表 1 高齢発症 RA と Control との当科初診時, 加療 1 年後，および 2 年後の検査結果

\begin{tabular}{|c|c|c|c|c|c|c|}
\hline & ESR & $\mathrm{CRP}$ & IgG-RF & RAHA & $\mathrm{IgG}$ & L.I. \\
\hline $\begin{array}{l}\text { Elderly-onset RA } \\
\text { (17 例) }\end{array}$ & $73.2 \pm 10.9$ & $5.8 \pm 1.7$ & $\begin{array}{c}2.5 \pm 0.5 \\
(6 \text { 人> }>2.0)\end{array}$ & $\begin{array}{c}2171^{*} \\
(3 \text { 人, 陰性) }\end{array}$ & $2152 \pm 226.1$ & $81.2 \pm 6.7$ \\
\hline $1 \mathrm{yr}$. & $41.4 \pm 6.8$ & $2.3 \pm 0.7$ & $1.7 \pm 0.3$ & 505 & $1556 \pm 85.9$ & $58.1 \pm 10.1$ \\
\hline 2 yrs. & $62.3 \pm 9.3$ & $4.1 \pm 0.8$ & $\begin{array}{c}2.0 \pm 0.5 \\
(4 \text { 人> }>2.0)\end{array}$ & $\begin{array}{c}1065 \\
\text { (4 人, 陰性) }\end{array}$ & $1497 \pm 107.6$ & $46.4 \pm 4.8$ \\
\hline $\begin{array}{r}\text { Control } \\
(19 \text { 例 })\end{array}$ & $54.2 \pm 6.3$ & $5.5 \pm 0.6$ & $\begin{array}{c}1.9 \pm 0.3 \\
(4 \text { 人> }>2.0)\end{array}$ & $\begin{array}{c}1123^{*} \\
\text { (5 人, 陰性) }\end{array}$ & $1917 \pm 228.1$ & $63.8 \pm 6.7$ \\
\hline $1 \mathrm{yr}$. & $28.4 \pm 10.5$ & $1.6 \pm 0.6$ & $1.4 \pm 0.3$ & 560 & $1563 \pm 145.2$ & $42.3 \pm 5.5$ \\
\hline $2 \mathrm{yrs}$. & $61.0 \pm 10.0$ & $4.0 \pm 0.9$ & $\begin{array}{c}1.7 \pm 0.3 \\
(4 \text { 人> }>2.0)\end{array}$ & 521.1 & $1609 \pm 113.8$ & $55.6 \pm 5.4$ \\
\hline
\end{tabular}

注 1) ESR, CRP, IgG-RF，血清 IgG，ランズバリー指数（L.I.）は平均士 SEMで現している.

注 2) $\mathrm{t}$ 検定にて RAHA の初診時に有意差 $(* \mathrm{p}>0.05)$ を認める以外, 両群間に統計学的有意差は認めない.

表 2 高齢発症 RA における抗リウマチ剂の有効性（継続性）および副作用の発現

\begin{tabular}{|c|c|c|c|c|}
\hline & シオゾール & リマチル & サラゾピリン & チオラ \\
\hline \multirow[t]{2}{*}{$\begin{array}{c}\text { 有効性 } \\
\text { (継続例／使用例） }\end{array}$} & $\begin{array}{c}6 / 10 \\
(+\mathrm{PSL} 4 \text { 例 })\end{array}$ & $1 / 5$ & $\begin{array}{l}\quad 2 / 4 \\
(+ \text { PSL } 2 \text { 例 })\end{array}$ & $1 / 3$ \\
\hline & $\begin{array}{l}10 \mathrm{mg} / \mathrm{w}, \text { or } \\
25 \mathrm{mg} / 2 \mathrm{w}\end{array}$ & $\begin{array}{l}100 \mathrm{mg} \\
/ \text { day }\end{array}$ & $\begin{array}{l}500-1000 \mathrm{mg} \\
/ \text { day }\end{array}$ & $\begin{array}{l}200 \mathrm{mg} \\
/ \text { day }\end{array}$ \\
\hline \multirow[t]{2}{*}{ 副作用 } & $\begin{array}{l}\text { 肝機能障害 } \\
1 \text { 例 }\end{array}$ & $\begin{array}{l}\text { 赤芽球疼 } \\
1 \text { 例 }\end{array}$ & $\begin{array}{l}\text { 肝機能障害 } \\
1 \text { 例 }\end{array}$ & $\begin{array}{l}\text { 肝機能障害 } \\
1 \text { 例 }\end{array}$ \\
\hline & $\begin{array}{l}\text { 腎機能障害 } \\
1 \text { 例 } \\
\text { (蛋白尿) } \\
\text { (NSAIDs } \\
\text { (PSL の初 }\end{array}$ & $\begin{array}{l}\text { 腎機能障害 } \\
3 \text { 例 } \\
\text { 出血性潰瘍 } \\
\text { 寺らの使用 }\end{array}$ & $\begin{array}{l}\text { 間質性肺炎増悪 } \\
1 \text { 例 }\end{array}$ & \\
\hline
\end{tabular}


陽性例を 4 例に認めた．対照群では陽性例は認めなかっ た．血清 IgG も両群ともに低下を認めるも，2000 以 上の高值例は高齢発症群に 2 例認めた。 LI の推移で は両群ともに若干の低下を認めるも明らかな改善は認 められなかった。

しかし 2 年後の結果では高齢発症群において炎症所 見の再燃がみられ, IgG-RF も平均 2.0 (陽性例 4 例) と増悪傾向を示したＬIIでは若干の改善を認めた。 一方対照群においてはより顕著に増悪傾向を認め, 炎 症所見では両群に全く差は認めなくなった。また対照 群で IgG-RF 陽性例を 4 例に認めたが，RAHA は 有意に低值を示した。

高齢発症群において抗りウマチ薬の継続率および副 作用を 2 年間でみてみると表 2 の如くであり，GST (シオゾール) の継続率が最も高かったが，10 例中 4 例にステロイド（プレドニン）を併用した。リマチル は $100 \mathrm{mg} /$ day にても副作用の頻度が高かった。リマ チル使用 1 年後に選択的赤血球系の障害である赤芽球 疼を 1 例に認めた。また腎機能障害の発現を高頻度に 認めた。サラゾピリンにおいて，間質性肺炎を増悪せ しめたと考えられた 1 例を経験した。なおプレドニン の初診時からの使用（2.5- $5 \mathrm{mg} / \mathrm{day})$ は単独例も含
め 17 例中 8 例であった。これとは別に NSAIDs（ジ クロフェナック）による重篤な出血性潰瘍（Hgb 6.0 まで低下）も経験した。

高齢発症群の 2 年間の経過中に 17 例中 9 例に合併 症を認めた，その内訳は間質性肺炎 2 例，糖尿病 1 例 および腎機能障害 3 例（ステロイドおよび抗りウマチ 薬によるものも含む）であったままたアミロイドーシ スの合併を 2 例に認め, うち 1 例は $\mathrm{RA}$ 発症後 1 年 以内で生じた。 アミロイドーシス合併のもう 1 万の例 では腎機能障害も有しており，RAの活動性も高くス テロイドの大量長期投与（PSL $10 \mathrm{mg}$ ）を余儀なく され, 高血圧のコントロールも難しく, 動脈硬化も進 んだためか脳出血を生じた。なお高齢に伴い 17 人中 10 人が RA 発症前に何らかの既往歴を有していた. その内訳は慢性閉塞性肺疾患 1 例, 糖尿病 2 例, 慢性 肝炎 2 例の他, 虚血性心臟病および不整脈等の心疾患 4 例，高血圧 5 例であった．以下症例を提示する。

症例 1 (図 1)，78 歳女性. 以前より高血圧，不整 脈，慢性心不全にて近医内科にて加療中であった. 1993 年 10 月多関節痛出現し, 同院にて RA の診断にてリ マチル $100 \mathrm{mg} /$ day 投与うけるも腎機能障害出現し中 止. RA コントロール困難であり両膝痛続くため当科

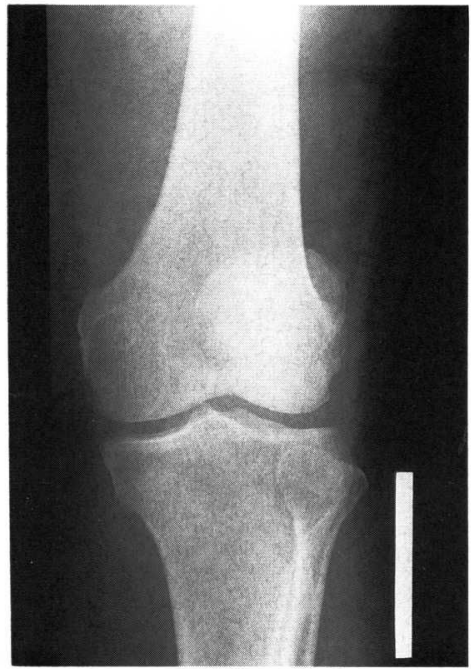

a )

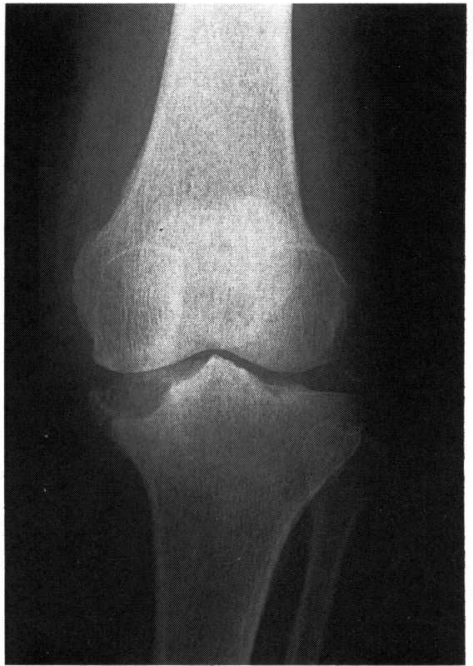

b )

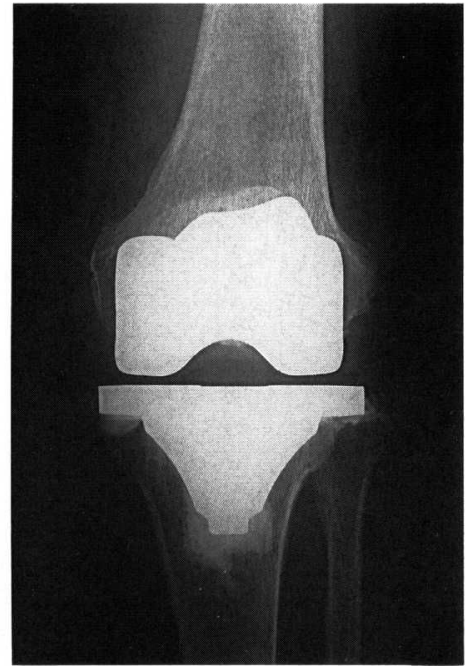

c)

図 1 症例 1）78歳女性，心不全，不整脈，腎機能障害の既往歴あり a) 1994 年 2 月当科紹介前, 血沈 $80 \mathrm{~mm} / 1 \mathrm{hr}, \mathrm{CRP} 8.6$, 膝痛のみ b) 1995 年 2 月術前, 血沈 $129 \mathrm{~mm} / 1 \mathrm{hr}$, CRP 10.0 , 歩行不能

c) 1996 年 10 月, 血沈 $48 \mathrm{~mm} / 1 \mathrm{hr}, \mathrm{CRP} 1.5$, 独歩可能 


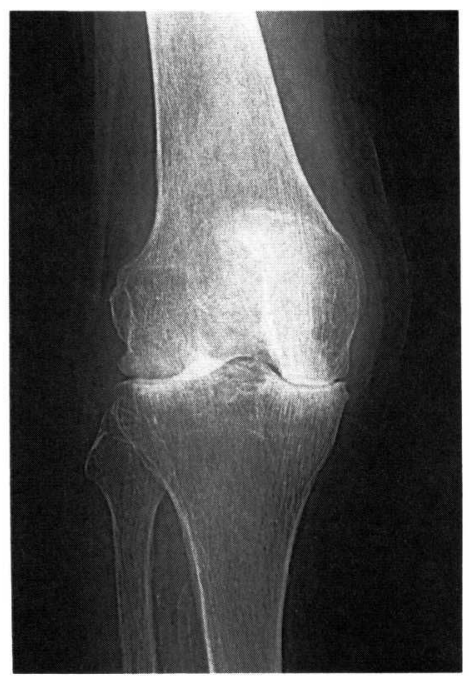

a)

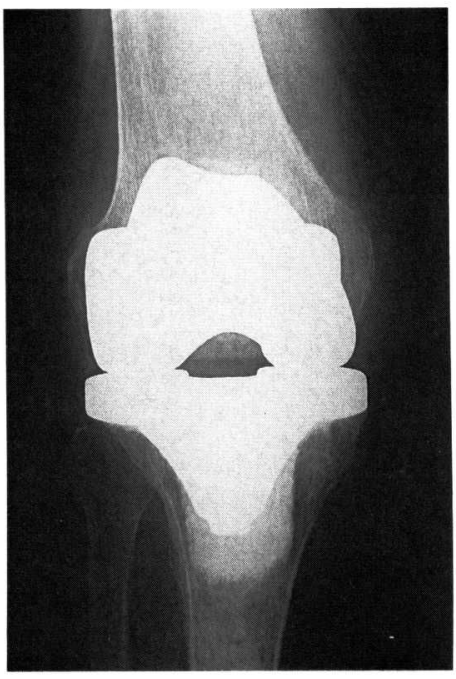

b )

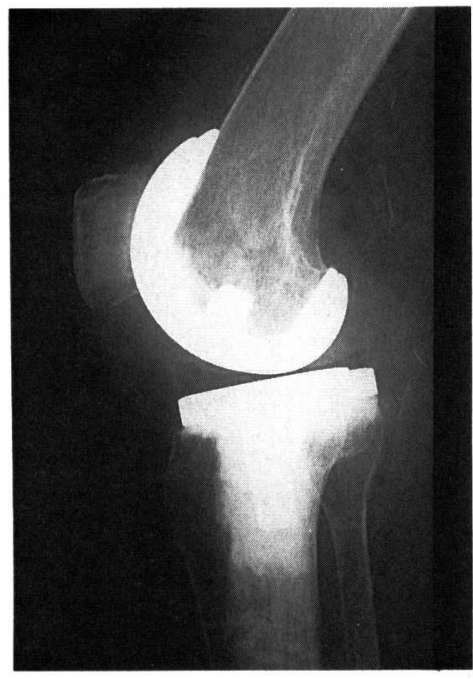

c)

図 2 症例 2 ) 69 歳女性, 糖尿病, ASO, 腎機能障害, 虚血性心臟病の既往歴あり a) 1994 年 4 月当科紹介時, 発症 6 年後

b ) 1996 年 9 月術後, 正面, 独歩可能

c ） 1996 年 9 月術後, 側面, 膝窩動脈に石灰化を認める

紹介となる。1994 年 2 月近医における当科紹介前の 膝レ線では軽度の変形性関節症の像である．当科受診 時腎機能障害顕著 $(\mathrm{CCr} 20 \mathrm{mg} / \mathrm{min}$ ) であり不整脈 および慢性心不全も認めた為, RA 活動性高度であっ たがNSAIDs（スリンダク）のみにて経過をみてい た. 1995年 2 月ほとんど歩行不能となり炎症所見も高 值が続いていたが, 腎障害も改善し (CCr 40mg/min), 心臓の状態も落ち着いた為両膝に人工関節置換術施行. 人工関節には Deltafit 7000 を用い, 大腿骨脛骨とも 骨セメントを使用した。また手術後ただちにプレドニ ン $5 \mathrm{mg} /$ day およびシオゾールの投与を開始した. 1996 年 10 月 RA 活動性も鎮静化し独りで外出してお り, 日常生活に満足している.

症例 2 (図 2), 70 歳女性. 以前より糖尿病にてイン スリンをうけており, それに伴う ASO, 腎機能障害, 末梢神経障害, 糖尿病性網膜症の他虚血性心臓病も合 併していた。 63 歳時 RA 発症, 近医にてシオゾール, リマチル，サラゾピリン， MTX 等のほとんど全ての 抗リウマチ薬の投与をうけるも, 副作用もしくは無効 にて中止. ステロイドの投与を余儀なくされていた. 1994 年 4 月膝痛強く歩行困難となり右第 1,2 趾に壊 疽も認めた為当科紹介. 血管障害, 神経障害も重篤で
ありまた骨粗鬆症による腰椎の破裂骨折も生じ, 腎 機能障害も顕著な為 ( CCr $17 \mathrm{mg} / \mathrm{min}$ ) 一端手術断 念したが, 本人の歩行に対する意欲強くProstagrandin 等用いながら，1995 年 4 月両膝に人工関節置換術 施行。人工関節には Deltafit 7000 を用い, 大腿骨脛 骨とも骨セメントを使用した。1996 年 10 月現在 1 本 杖での独歩可能となっているが, 糖尿病とともに RA のコントロールも難しく慎重な治療を必要としている.

\section{考察}

現在までの cross sectional study では高齢発症 RA は若年発症 RA に比べ予後は良好とされている が，その中にはリウマチ性多発性筋痛症や骨破壊をも つ変形性関節症などの症例が多く含まれていたとされ ている ${ }^{2)}$. Desiree らは, 高龄発症 RA は関節機能障 害がより高頻度であったとしており ${ }^{2)}$ ，和田らも高齢 発症 RA には ESR 高值, RF 高值, 関節外症状の合 併を多く認め，かつ RAの活動性もより高く，治療 に対する反応性も不良であったと報告している 方島岡らは高齢発症 RA の多くは発症後 2 年から 4 年にかけて関節破壊が進行するも, 5 年以降は鎮静化 すると述べている7). また溝上らも高齢発症 RA と若 
年発症 RAの予後に差はなかったと報告している5). 我々の症例においては以前より内科にて加療中に RA 発症した例が多く偏りがあることは否めないが、これ も高齢発症 RA の一つの側面とするならば RAHA （IgM-RF）高値，IgG-RF 高值にて関節外症状の合 併を多く認めかつ RA の活動性も若年発症 RA と同 じ程度に高いと言えよう。

また島岡らは OA 罹患のある症例に RA が発症し た場合急速に関節破壊が進行すると述べているが7), 我々も症例 1 のようにNSAIDs のみにて経過観察し たところ炎症が持続し，急速に関節破壊が進行した例 を数例経験しており, 発症初期における早急な炎症の 鎮静化はやはり必要と考える. それ故発症初期に積極 的な薬物治療をした状態での高齢発症 RAの予後と いうものには今後の検討を要する.

しかしながら薬物療法において van Schaardenburg らは，特にRF 陽性の高齢発症 RA において抗りウ マチ剤の副作用の発現がより多かったと報告してお $\eta^{6)}$, Terkeltaub らも注射用金郕およびD - ペニシ ラミンにおいて副作用の発現は, 若年発症 RA に比 し 2 倍以上 $(53 \%: 24 \%)$ 高齢発症 RA に高頻度で あったとしている ${ }^{8)}$. 一方 Dahl らは年令自体は抗リ ウマチ剂の副作用の発現に差をもたらせないとしてい るが')，今回の我々の検討でもはっきりとした副作用 として肝機能障害や特にリマチルにおける早期からの 腎機能障害の発現の他, リマチル投与中に赤芽球疼を 生じた例や，サラゾピリン投与中に間質性肺炎の急性 増悪を生じた例など副作用かどうか明らかではないが 中止とした例もあり，やはり薬剤の選択には慎重であ るべきと考える. 尚実際の投与においては 2 年間の観 察期間においてシオゾールは常用量にて副作用も少な く, 炎症所見や関節点数の改善もみられた為, 初診時 からの投与例も多く継続度も高くなった. 古市らの報 告でも発症 1 年未満の高齢発症 RA において低量金 療法が臨床効果が早期に現れ反応性が高いとしている $か^{33)}$, 前述の如く副作用に注意すれば第一選択薬とし てシオゾール $25 \mathrm{mg} / 2 \mathrm{w}$ の投与でも適当と思われた. また Lockie らは高齢発症 RA においてはステロイ ドの少量投与が有効であると述べているが4), 特に活 動性の高い高齢発症 RAに打いて炎症を早急に鎮静 化させることが必要であり，抗りウマチ鼡が効果発現 するまで時間を要する事からも早期のステロイド少量
投与は必要と考え今回 8 例に併用した。しかし溝上ら は高齢発症 RA の高血圧や糖尿病の合併率は一般人 の約 3 倍であると述べており ${ }^{5)}$, 今回の我々の結果で もステロイドに起因すると思われる糖尿病および脳出 血の発生をみた他, 既往歷として高血圧や糖尿病およ びその他の慢性疾患を有している例が多く，ステロイ ドには骨粗筑の促進の他耐糖能の低下, 高血圧の増悪, 動脈硬化の促進などといったデメリットも多いことか ら早期投与には今後も検討を要する．なお一例ではあ るが NSAIDsにて重篤な出血性潰瘍を生じた例も経 験しており，十分注意を要する．2 年間の間に間質性 肺炎の発症を 2 例，アミロイドーシスの合併を 2 例, そして腎機能障害を 4 例に認めたことも注意を要する. しかしそれらのことを踏まえておけば提示症例のよう に人工関節により独歩可能となり患者の満足度も高い ことからも, 今後も Quality of life の観点から手術 等のより積極的なアプローチは必要と考える.

結語

(1) 60 歳以降に発症し， 2 年間以上観察しえた RA 患者 17 名について検討を加えた。

(2)発症初期にコントロールされていないものや，変 形性関節症がベースにあるものに急速な骨破壊を認め た。また関節外症状の発現も多く認め十分な注意を必 要とした. RAHA, IgG-RF は 50 歳未満に発症し たものに比し高值を示す傾向にあった.

(3) DMARDs ではシオゾールの継続率が最も高かっ た. DMARDs 投与 1 年後検查結果は改善傾向を示 すも， 2 年後には再び悪化を認めた. しかし Lansbury Index（特に関節点数）は改善傾向を示した.

(4)高齢発症の RA 治療にはより慎重さが求められ る一方, 発症早期に急速な骨破壊を認める例もあり， Quality of lifeの観点から人工関節等のより積極的 かつ具体的アプローチが必要である.

\section{参 考 文 献}

1) Dahl, S. L. et al.: Second-line antirheumatic drugs in the elderly with rheumatoid arthritis: a post hoc analysis of three controlled trials. Pharmacotherapy, $10: 79-84,1990$.

2) Desiree, M. et al.: Older versus younger onset rheu matoid arthritis: results at onset and after 2 years of a prospective follow-up study of early rheumatoid 
arthritis, J. Rheumatol., 18 : 1285-1289, 1991.

3）古市 格ほか: 高齢発症慢性関節りウマチに対する金 療法の検討.九州リウマチ, $13: 152-156,1994$.

4) Lockie, L. M., Gomes, E., Smith, D. M.: Low dose adrenocorticosteroid in the management of elderly patients with rheumatoid arthritis: selected examples and summary of efficacy in the long term of 97 patients. Semin. Arthritis Rheum., $12: 373-384,1983$.

5）溝上明成ほか：高龄発症慢性関節リウマチの臨床的特 徵. 九州リウマチ, $13: 6-10,1993$.
6) van Schaardenburg, D. et al.: Outcome of rheumatoid arthritis in relation to age and rheumatoid factor at diagnosis. J. Rheumatol., $20: 45-52,1993$.

7）島岡康則ほか: 高齢発症慢性関節リウマチの自然経過, 成人発症例との比較. 中部リウマチ, $25: 1-9,1994$.

8) Terkeltaub, R. et al.: A clinical study of older age rheumatoid arthritis with comparison to a younger onset group. J. Rheumatol., $10: 418-424,1983$.

9）和田哲也ほか: 高秢発症慢性関節リウマチの特徵. 九 州リウマチ, 13 : 1-5, 1993. 